\title{
Palaeolimnological reconstruction of recent environmental change in Lake Malombe (S. Malawi) using multiple proxies
}

\author{
Zuze Dulanya ${ }^{1,2 *}$, Ian Croudace ${ }^{3}$, Jane M Reed' and Martin H Trauth ${ }^{2}$ \\ 'Department of Geography, University of Hull, Cottingham Road, Hull HU6 7RX, UK \\ ${ }^{2}$ Universität Potsdam, Karl-Liebknecht-Str. 24, D-14476 Potsdam, Germany \\ ${ }^{3}$ Radioanalytical Laboratories, National Oceanography Centre, Southampton SO14 3ZH, UK
}

\begin{abstract}
Shallow inland water bodies in Malawi continue to be threatened by various environmental challenges despite their importance to the fisheries industry. Due to the complex interaction between natural and anthropogenic disturbances, disentangling the effect of the two may be a complicated process. The littoral zone of most water bodies is important in environmental reconstructions including pollution and lake level monitoring. This study used a littoral zone, transectbased approach employing multi-proxy palaeolimnological techniques to reconstruct recent environmental change (ca. 100 yrs.) in Lake Malombe in the Malawi Rift, East Africa. The results of the study could inform fisheries management in Lake Malombe, which experienced a catastrophic decline in fish stocks. Results support documentary evidence for the complete desiccation of the lake less than 100 years ago. Subsequently, there is evidence for accelerated eutrophication in the recent past. In light of these results, it is concluded that transect sampling approaches rather than relying on single core measurements, and the need for careful consideration of the types of proxy, are significant considerations in palaeoenvironmental reconstructions.
\end{abstract}

Keywords: littoral zone, palaeolimnology, diatoms, Lake Malombe

\section{INTRODUCTION}

A traditional emphasis in palaeolimnological research has been on the reconstruction of long-term $\left(10^{3}\right.$ to $10^{4}$ years $)$ climate change and its influence on the flora and fauna, including humans (Stager et al., 2005; Veski et al., 2005; Scholz et al., 2007; Plater et al., 2008). With concerns over recent degradation of water quality (e.g. acidification, eutrophication, salinisation) in the developed world, the value of the palaeolimnological approach in reconstructing the timing and magnitude of the most recent $\left(<10^{3}\right.$ years) impact on the environment (Battarbee, 1999), and in defining the reference or baseline state for restoration (Bennion et al., 2001; Sayer and Roberts, 2001), is now well recognised.

Water quality issues are of increasing concern in the less developed world but water-quality monitoring and management practices are often not yet implemented, and the potential contribution of the palaeolimnological approach has not been tested. In sub-Saharan Africa, for example, monitoring techniques for water chemistry and aquatic invertebrates have been developed but, as in western Europe until the advent of the EU Water Framework Directive (Barbour et al., 2000; Keller and Cavallaro, 2008; Kelly et al., 2008), tend to be applied in a piecemeal fashion. With the exceptions of Lake Victoria region, Kenya and South Africa (Hecky, 1993; Mpawenayo and Mathooko, 2005), very little progress seems to have been made. In Malawi, studies are limited to small-scale monitoring

\footnotetext{
* To whom all correspondence should be addressed.

Current address: Geography and Earth Science Department,

University of Malawi, PO Box 280, Zomba, Malawi

용 +26599125 9515; e-mail: zuzedulanya@yahoo.com

Received 31 December 2012; accepted in revised form 6 October 2014.
}

projects which are not sustained for long enough to understand the limnological system. This is in part due to resource constraints and the lack of the necessary scientific culture to manage water resources (Bootsma and Jorgensen, 2005).

In the absence of monitoring data, the palaeolimnological approach offers the potential to infer past environmental conditions of lakes and their catchments (Battarbee, 1999, 2000). The multi-proxy approach has greater potential to generate reliable palaeo-environmental reconstructions than undue reliance on a single proxy, however powerful it may be (Sayer et al., 1999; Annadotter et al., 1999; Ryves et al., 2011). This is because environmental response in lakes could be affected by various forcing mechanisms operating at the same time (Battarbee et al., 2005). A classic example is the ambiguity of a relative increase in planktonic diatoms, which may arise either from increased productivity, or from increased lake level (Wilson et al. 2008). Owing to these factors, several proxies are used for environmental reconstructions, such as pollen, diatoms, and other biogeochemical proxies. Diatoms (Bacillariophyceae), are strong palaeo-environmental proxies owing to their rapid response to environmental change, their ease of identification and preservation in a wide range of lacustrine habitats (Stoermer and Smol, 1999; Bellinger et al., 2006). However, they are sufficiently diverse (species richness being estimated as ranging from $10^{4}$ to $10^{5}$ species; Stoermer and Smol, 1999) that their taxonomy is not yet fully understood, particularly for regions which have not been the object of sustained research. Molluscs, as another example of a proxy, are found in a wide range of environments and have different levels of tolerance. Their distribution is limited by the water depth column and therefore the amount of oxygen circulation, the substrate and salinity. Knowledge and understanding of mollusc behaviour and ecology enables the reconstruction of palaeo-environmental conditions in an area because of their particular association with certain substrates. 


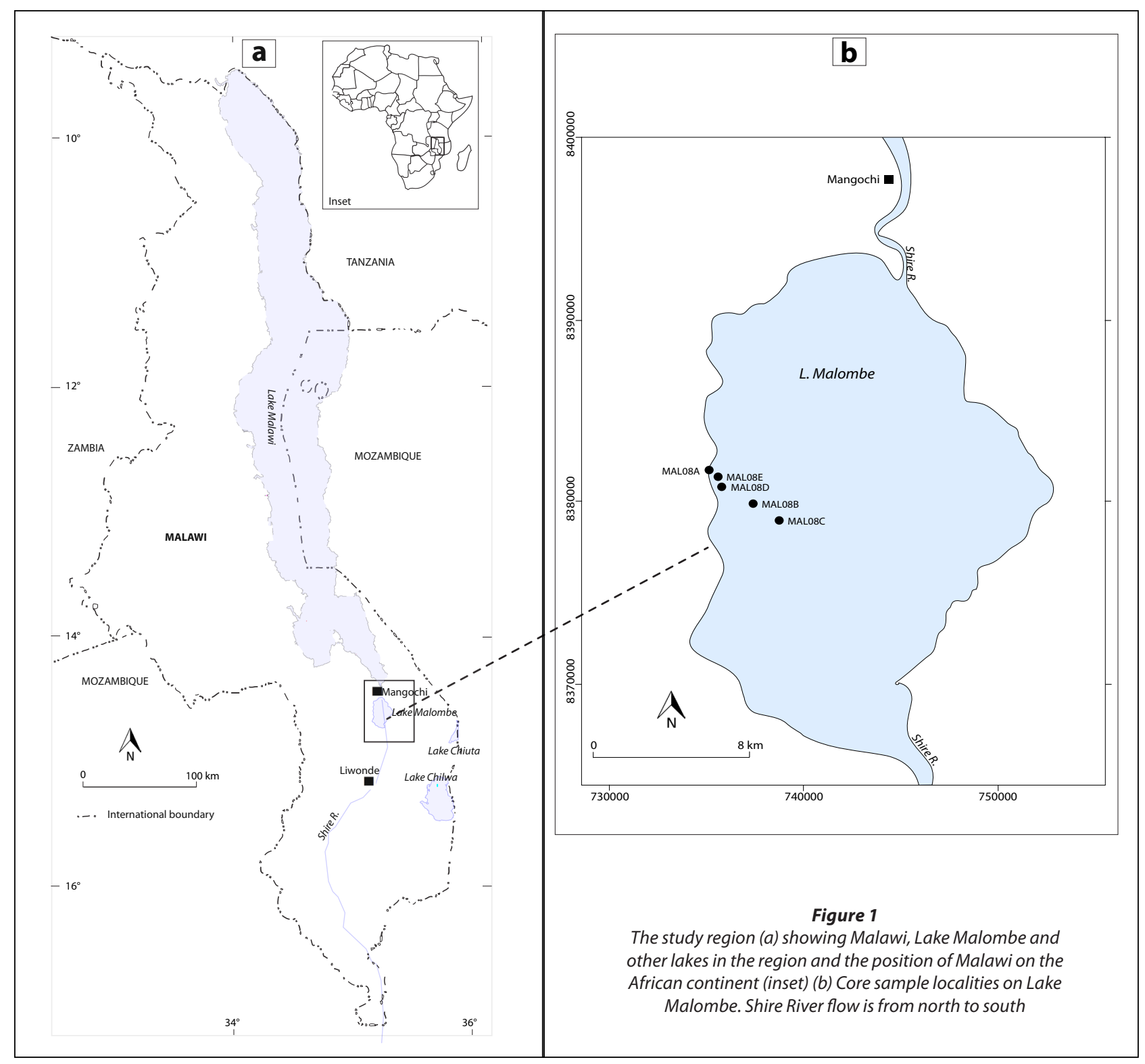

Palaeolimnological research in eastern sub-Saharan Africa has tended to focus on the large, deep ancient lakes of the western branch of the East African Rift System (EARS), paying specific attention to tectonism, biodiversity and endemism, and long-term climate change and human impact (Owen et al., 1990; Scholz et al., 2007). Considering the widespread environmental exploitations and the consequent degradation rampant in this region, little attention has been paid to understanding the effects of these activities on water quality, although studies are beginning to emerge (Kolding et al., 2008, Otu et al., 2011). In Malawi, limnological and palaeolimnological studies have focused on Lake Malawi and the shallow, saline, Lake Chilwa (Moss and Moss, 1969; Kalk et al., 1979; Lancaster, 1981; Thomas et al., 2009). Lake Chilwa is classified as a UNESCO World Heritage Site on the grounds of its bird diversity while Lake Malawi is widely acknowledged for its biodiversity and endemism and fresh water (Snoeks, 1998; Kling et al., 2001). Despite the interest in these two lakes, the spatial coverage of these studies is limited and thus the short- to medium-term trajectories of environmental change due to anthropogenic disturbance of the region are not adequately known. Meanwhile, the small and shallow lakes which are important economic resources continue to suffer from degradation. The southern end of Lake Malawi and Lake Malombe with their disturbed catchments and shallow depths are ideal sites for such studies (Otu et al., 2011).

Lake Malombe is an important fisheries ground for smallscale artisanal fishermen within the western branch of the EARS. In spite of its small size compared to Lake Malawi, it used to provide approx. $10 \%$ of the national total fish catch and is an important breeding ground for some fish species such as Oreochromis spp (GOM/FAO/UNDP, 1993). Oreochromis spp., for example, are known to move to shallower depth, e.g., in Lake Malombe, during the breeding season and some of them migrate up the Shire River into Lake Malawi at the proper age (GOM/FAO/UNDP, 1993). Thus the lake is strategic for fisheries conservation for some of Lake Malawi's fish species. However, the fisheries industry in Lake Malombe collapsed in the early 1990 s and is yet to recover. This collapse has been attributed entirely to overfishing (GOM/FAO/UNDP, 1993; Msiska and Lwanda, 2008). The degree to which water quality degradation 
may contribute is yet to be tested. In spite of some evidence that suggests that water quality and the environment around the lake seem to be compromised, no work has yet been undertaken at a detailed scale to test this. As an example, there is a noticeable increase and compositional shifts of mollusc shells along the lake's beaches from the predominant and endemic Lanistes spp. to Melanoides spp. (Genner et al., 2004; Schultheiß et al., 2009). An increase in sudds and water hyacinth (Eichhornia crassipes) may indicate nutrient enrichment and other forms of environmental degradation within the catchment basin of this lake (Hecky et al., 2003; Palamuleni et al., 2011). A proper management plan for this water body requires a clear understanding of the major drivers of environmental change. This study aimed to generate baseline environmental information necessary to inform natural resource management for the Lake Malombe region, using palaeolimnological techniques.

\section{STUDY AREA}

\section{Location}

Lake Malombe is approx. $470 \mathrm{~m}$ asl and is situated between latitudes $14^{\circ} 30^{\prime} \mathrm{S}$ and $14^{\circ} 45^{\prime} \mathrm{S}$ and longitudes $35^{\circ} 12^{\prime} \mathrm{E}$ to $35^{\circ} 20^{\prime} \mathrm{E}$ (Figs 1a and 1b). It is found some $10 \mathrm{~km}$ to the south of Mangochi Township.

The lake occupies the southern-end of the Lake Malawi graben with the western margin partly fault-controlled. The rift floor is filled with alluvial sediments of varying compositions (Carter and Bennett, 1973).

\section{Climate, hydrology and limnology}

Malawi has two main seasons, comprising a cool dry season between May and October with mean temperatures of around $13^{\circ} \mathrm{C}$ in June and July, and a hot wet season between November and April with mean temperatures between 30 and $35^{\circ} \mathrm{C}$. Rainfall is variable depending on altitude, ranging from 600 $\mathrm{mm} / \mathrm{a}$ on the rift valley floors to $1600 \mathrm{~mm} / \mathrm{a}$ in mountainous areas. The climate of the region is largely influenced by the seasonal migration and intensity of the intertropical convergence zone (ITCZ), a low pressure belt within the Congo basin caused by tropical high pressure belts over both the Indian and Atlantic Oceans (Nicholson and Yin, 2001) and the Congo Air Boundary (CAB), controlled by sea-surface temperature (SST) anomalies such as the Indian Ocean Dipole (IOD) and El Niño/ Southern Oscillation (ENSO) system (Abram et al., 2007; Saji et al., 1999). Local differences in rainfall are caused by complex topography causing deflections of moisture-bearing winds that are responsible for precipitation and rain-shadow effects in various environments.

Lake Malombe formed as a result of ponding out of the Shire River, and is essentially a large oxbow lake, with Shire flow running through the centre of the basin (GOM/FAO/UNDP, 1993). The lake lies within a tropical rainfall belt with excessive evapotranspiration. In periods of extreme aridity when the levels of Lake Malawi are too low to allow any outflow into the Shire River (Kanthack, 1941; Owen et al., 1990), Lake Malombe becomes an independent hydrological system dominated by surface and groundwater recharge and evapotranspiration. For example when, Lake Malawi dropped to its lowest level of $470 \mathrm{~m}$ asl at the beginning of the last century, the outflow into the lake ceased from 1915-1935 (Kanthack, 1941; Shela, 2000).

No lake-level monitoring has yet been carried out on Lake Malombe. Because of its hydrological connection, however, its behaviour is likely to be influenced strongly by Lake Malawi. The link between the two basins is due to their shared catchment, with part of Lake Malawi's catchment straddling both a subequatorial and tropical rainfall belt (Owen et al., 1990; Nicholson, 1998; Castañeda et al., 2007), in the north and south, respectively. In view of the foregoing, Lake Malombe's behaviour may be influenced by both the subequatorial and tropical climate systems, unlike other shallow independent lakes in similar geographical settings. As a result, the lake's water budget is largely responsive to the effects of both precipitation and evapotranspiration.

Lake Malombe has a generally flat bed with a channel gradient between Mangochi and Liwonde that is nearly horizontal, changing by approx. $1.5 \mathrm{~m}$ over a distance of $87 \mathrm{~km}$ (Shela, 2000). It has a maximum length of approx. $29 \mathrm{~km}$ and a width of approx. $17 \mathrm{~km}$. The maximum depth is $6 \mathrm{~m}$, with a surface area of approx. $390 \mathrm{~km}^{2}$. The lake was previously classified as having a mean chlorophyll $a$ concentration of $4.6 \mathrm{mg} \cdot \ell^{-1}$ in 1991-1992 and Secchi depth of 2.4 at 4-m depth (GOM/FAO/UNDP, 1993).

\section{METHODOLOGY}

Sediment cores were obtained during the calm, dry season in August 2008. For navigation around the lake, a fisherman's plank boat was used. Transect sampling was done to reconstruct lake-level changes by reconstruction of changes in the littoral zone (Digerfeldt, 1986), and to test the integrity of the stratigraphic record of the lake. This technique is stronger in reconstruction of changing location of shorelines if lake-level change or eutrophication occurred (Digerfeldt, 1986, Kitner and Poulickova, 2003). Suitable core sample sites were identified using a hand-held echo sounder for depth sounding. Geographic coordinates were recorded using a Garmin Etrex GPS receiver and turbidity was determined using a Secchi disk. After anchoring the boat, the soft sediment was retrieved from the lakebed using an Uwitec ${ }^{\circ}$ gravity corer with 1-m tube attachment. In total, 5 cores were collected, denoted as the codes MAL08A, MAL08B, MAL08C, MAL08D and MAL08E (Fig. 2). Cores could not be collected from the centre of the lake due to a relatively strong current, which must have been derived from the flow of the Shire. Samples were extruded in the field into $1-\mathrm{cm}$ thick subsamples, except for the topmost $1 \mathrm{~cm}$, which was sampled at $0.5-\mathrm{cm}$ resolution for investigation of modern ecological change. Samples were stored in sterile Whirlpak

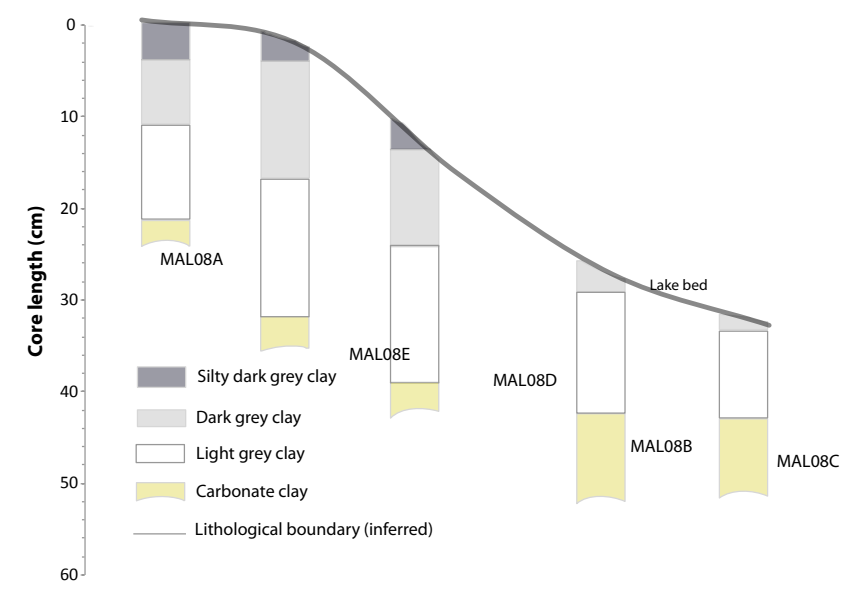

Figure 2

Core characteristics from the transect area 
bags, and kept refrigerated during most of the sampling session prior to storage at $4^{\circ} \mathrm{C}$ in the UK.

\section{Laboratory analyses}

\section{Chronology}

Core MAL08A,was selected as a master core for dating, on the grounds that it was one of the cores nearest to the littoral zone, and thus ideal for recording ecological changes emanating from the littoral zone while at the same time being subjected to fewer influencing factors from the flow of the Shire River. The core was dated using Caesium-137 and Lead-210 at the University of Southampton. The method used was gamma spectrometry after transferring the samples into scintillation vials. The sample was then counted on a well-type HPGe detector previously calibrated with a mixed nuclide standard of identical geometry. The resulting spectrum was analysed using Fitzpeaks spectral analysis software. Limits of detection were calculated as defined by Currie (1968) and Gilmore and Hemingway (2000) as follows:

$$
\begin{aligned}
L_{Q(\text { gamma })}= & 0.5 \times \sigma^{2} \times\left(1+\sqrt{1+\left(4 \times\left(1+\frac{n}{2 m}\right) \times \frac{C}{\sigma^{2}}\right)}\right) \\
& \times \frac{1}{t} \times \frac{100}{E} \times \frac{100}{Y} \times \frac{1}{M_{g}}
\end{aligned}
$$

where:

$\sigma$ is set at 2.00

$C$ is the background count

$n$ is the number of channels covering the peak

$m$ is the number of background channels taken either side of the photopeak

$t$ is the count time in seconds

$E$ is the counting efficiency

$Y$ is the gamma emission probability

$M_{g}$ is the mass of sample analysed in grams.

A clay carbonate horizon at the bed of Lake Malombe provided an additional approximate chronological data for all core sequences. This clay was previously reported and explored for its potential use in cement manufacturing in the 1920-1930's (Nyasaland Protectorate, 1926; Dixey, 1932) when the lake dried. The depth to this layer is variable from one sample locality to another, and is clearly defined on the basis of loss on ignition (LOI).

\section{Diatom preparation, identification and counting}

Diatoms were prepared using standard techniques according to Battarbee (1986), from approximately $0.2 \mathrm{~g}$ of wet sediment. Hot $30 \%$ hydrogen peroxide $\left(\mathrm{H}_{2} \mathrm{O}_{2}\right)$ and $10 \%$ hydrochloric acid were added to the sample in order to remove organic matter and carbonates, respectively. The remaining sample was neutralised and cleaned with de-ionised water and centrifuged 3-5 times at $1200 \mathrm{r} / \mathrm{min}$. Residues were dried on cover slides and microscope slides were prepared using Naphrax ${ }^{\odot}$. The diatom taxonomy used followed Krammer and Lange-Bertalot (1986; 1988; 1991a, b) and Gasse (1986), with updated nomenclature. An Olympus BX45 light microscope was used with oil immersion and magnification at $1000 \mathrm{x}$ for counting diatom assemblages along the transect; 500 valves per slide were counted where preservation permitted. Diatom data were presented using Tilia and TgView (Grimm, 1991). Stratigraphic zone boundaries were defined using Constrained Incremental Sum of Squares (CONISS) software (Grimm, 1987). Ecological data were taken from Gasse et al. (1995) and the European Diatom Database Initiative (EDDI) (Eddi, 2012; Battarbee et al., 2001).

\section{Loss on ignition}

Loss-on-ignition (LOI) analyses were carried out in the laboratory by weighing subsamples of approx. $0.5 \mathrm{~g}$ wet weight. The subsamples were placed in weighed crucibles and re-weighed to 3 decimal places. Weight loss was measured after heating at $105^{\circ} \mathrm{C}$ overnight to remove water. For carbon and carbonate estimation, the dried subsamples were oxidised at $500-550^{\circ} \mathrm{C}$ and $900-1000^{\circ} \mathrm{C}$, respectively (Dean, 1974 ; Heiri et al., 1999). Percentage organic content was estimated by dividing the difference between the mass of dry sediment sample and the sediment heated by the weight of the dry sediment (Dean, 1974; Heiri et al., 1999). Carbonate content was estimated by dividing percentage LOI at $950^{\circ} \mathrm{C}$ by 0.44 , assuming a $\mathrm{CO}_{2}$ molar weight of $44 \mathrm{~g} \cdot \mathrm{mol}^{-1}$ (Dean, 1974; Heiri et al., 1999).

\section{RESULTS}

\section{Water quality}

The results of depth sounding, water depth and Secchi disk measurements are shown in Table 1.

TABLE 1

\begin{tabular}{|l|c|c|c|}
\hline \multicolumn{5}{|c|}{ TABLE 1} \\
\hline Characteristics of sediment cores from Lake Malombe \\
\hline Mal08A & $\begin{array}{c}\text { Core } \\
\text { length }(\mathrm{cm})\end{array}$ & $\begin{array}{c}\text { Water } \\
\text { depth }(\mathrm{m})\end{array}$ & $\begin{array}{c}\text { Secchi } \\
\text { depth }(\mathbf{m})\end{array}$ \\
\hline Mal08B & 30 & 3.7 & 0.9 \\
\hline Mal08C & 24 & 4.6 & 1.2 \\
\hline Mal08D & 28 & 4.8 & 1.3 \\
\hline Mal08E & 26 & 3.6 & 1.3 \\
\hline
\end{tabular}

The depth sounding indicated that the lake is shallow (maximum depth $<5 \mathrm{~m}$ ) with a gently sloping lake bed. Schematic bathymetric sections based on the five sample points of the transect segment (Fig. 2) indicated that the slope is gentler on the eastern side of the lake than the western. In addition, the study showed that the cores near the shore are generally longer than those farther from the shore. This is counterintuitive, and probably reflects the influence on sediment accumulation rate of the flow of the River Shire through the centre of the lake.

\section{Turbidity}

Secchi disk measurements, taken at each point of the bathymetric survey, indicate a decrease in water clarity along a NW-SE gradient. The Secchi disk measurements range from 0.9 to 1.3 $\mathrm{m}$ with a mean depth of $1.1 \mathrm{~m}$ light penetration.

\section{Sediment characteristics}

Cores MAL08A, MAL08D and MAL08E are made up of medium- to dark-grey clay $(2.5 \mathrm{Y}, 4 / 1)$ with varying amounts of organic debris and silty clay. Near the core base of MAL08A (from approx. 26 to $31 \mathrm{~cm}$ depth), dark and hard organic-rich 


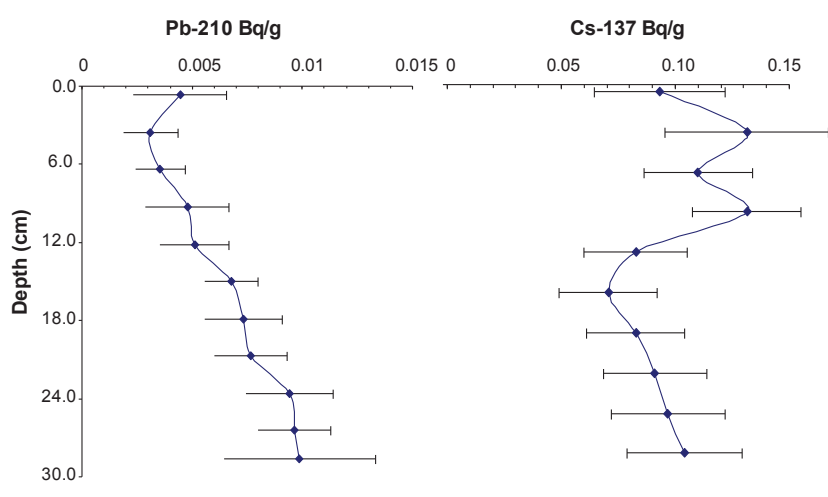

Figure 3

Cs-137 and Pb-210 profiles for MALO8A

sediment was found. Apart from organic matter, the top silty sediment is rich in other mineral constituents, which are the characteristic minerals from the riparian basement complex rocks (Manyozo et al, 1984). The colours of cores MAL08B and MAL08C grade from medium- to light-grey (2.5Y, 6.5/1) to light-grey in carbonate-rich clays (10YR 8/1). The reconstructed idealised stratigraphic column for the sediment cores is shown in Fig. 2. A sharp contact between the light-dark grey clays and the carbonate clays was encountered. At the contact, the carbonate clays occur in the form of lumps within the dark-grey clays together with some organic matter and gradually grading into pure carbonate clays at greater depth.

\section{Core chronology}

Radiometric dating results suggest either a very young sediment record (post-1960s) or a mixed sediment sequence based on the linear behaviour and multiple peaks in the $\mathrm{Pb}-210$ and Cs-137 curves, respectively (Fig. 3). The latter is not in accord with the clear stratigraphic boundaries displayed by the diatom and LOI data below.

In view of these results, core chronology has been based on LOI results, taking the age of the base of the core as approx. $1920 \pm 10$ years when the lake dried (Dixey, 1932). Inter-core variability is evident in the diatom stratigraphic record. This probably suggests that sediment accumulation has been uneven across the lake, possibly due to the influence of more rapid flow from the Shire River towards the centre of the lake basin. However presence within certain stratigraphic sequences of certain fossils can be used to correlate and build up the complete lake environmental history.

\section{Diatom stratigraphy}

A total of 40 different diatom species were observed in the sediment cores from Lake Malombe. Except for MAL08D, cores MAL08A and MAL08E, which are near the shore, have the greatest diatom diversity compared to MAL08B and MAL08C, which were near the centre of the lake. MAL08D, which was near the shore, had the lowest diatom diversity (12 species with abundance $\geq 1 \%$ ).

Species showed a remarkable composition consistency from one core to the other (Figs $4 \mathrm{a}-\mathrm{e}$ ) with variations in depth of zone boundaries among the various cores. Species abundance diagrams were plotted for all diatom species greater than $1 \%$, except for MAL08E where the abundance was low. A number of taxa were found with abundance $\leq 1 \%$. These are presented in Table 2 together with their ecological conditions.

Cosmopolitan species are the most abundant throughout the cores followed by the benthic species at greater depth. The dominant cosmopolitan species, comprising $20-40 \%$ in all samples, include the Fragilariales (Williams and Round, 1987), such as Pseudostaurosira brevistriata Williams and Round, Staurosirella pinnata Williams and Round, Staurosira construens var. construens Williams and Round and Staurosira construens var. venter Williams and Round. Others include Staurosirella lapponica Williams and Round, S. biceps Williams and Round and S. africana Williams and Round. Deformation of $S$. construens var construens was observed near the littoral zone in cores MAL08D and MAL08E.

Benthic diatoms are the second-most abundant group in the lower parts of the cores. They show a progression in both abundance and composition from euryhaline species, e.g., Amphora lybica and A. pediculus (some cores) near the bottom of the cores, through muddy to freshwater, and finally to Nitzschia-Fragilaria species at the top parts of the cores. They are dominated by assorted Navicula and Surirella species. Of the latter, S. engleri is dominant and the type-name S. malombae quite rare. Navicula capitoradiata, characteristic of fresh to oligosaline waters (Gasse, 1986) is common in certain parts of the cores. Other benthic taxa include Caloneis bacillum, Sellaphora pupula, assorted Nitzschia species, e.g., N. desertorum Hust., N. nyassensis O. Müller, N. palea Kütz, Cymbella muelleri O. Müller, Cocconeis thumensis Mayer and C. placentula Ehr., Fragilaria rumpens Kütz, F. tenera Kütz and F. acus Kütz.

At shallower core depth, there is a two- to threefold increase in abundance of planktonic species compared to deeper parts of the cores, for all the cores. The dominant planktonic species include Aulacoseira granulata (Grün) Simonsen,

\begin{tabular}{|l|l|l|}
\hline \multicolumn{2}{|c|}{ Some of the less abundant diatom species from Lake Malombe cores } \\
\hline CORE & SPECIES & ECOLOGY \\
\hline \multirow{2}{*}{ All cores } & Hantzschia amphioxys Ehr. (Grün.) & $\begin{array}{l}\text { Distribution of these species is also related } \\
\text { to ephemeral conditions. Species may also } \\
\text { found in chloride or carbonate waters. }\end{array}$ \\
\hline MAL08A, MAL08E & Stauroneis crucicula, Rhopalodia spp. (Ehr.) O. Müller & Epiphytic and bottom-dwelling \\
\hline MAL08D & Epithemia spp. (Kütz) Grün. & \\
\hline MAL08E & Cymbella spp. (A. Cleve) O. Müller, Kütz, Gasse, Grün. & Littoral and epiphytic \\
\hline \multirow{2}{*}{ MAL08B } & Anomoeoneis sphaerophora O. Müller; A. spp. (Kütz), Schmidt & Euryhaline conditions \\
\cline { 2 - 3 } & Cymbellonitzschia spp. Hust. & Sandy environments \\
\hline MAL08A & Neidium iridis, N. dubium & Euryhaline, eutrophic conditions \\
\hline MAL08A & Gyrosigma obtusatum & Muddy environment \\
\hline
\end{tabular}



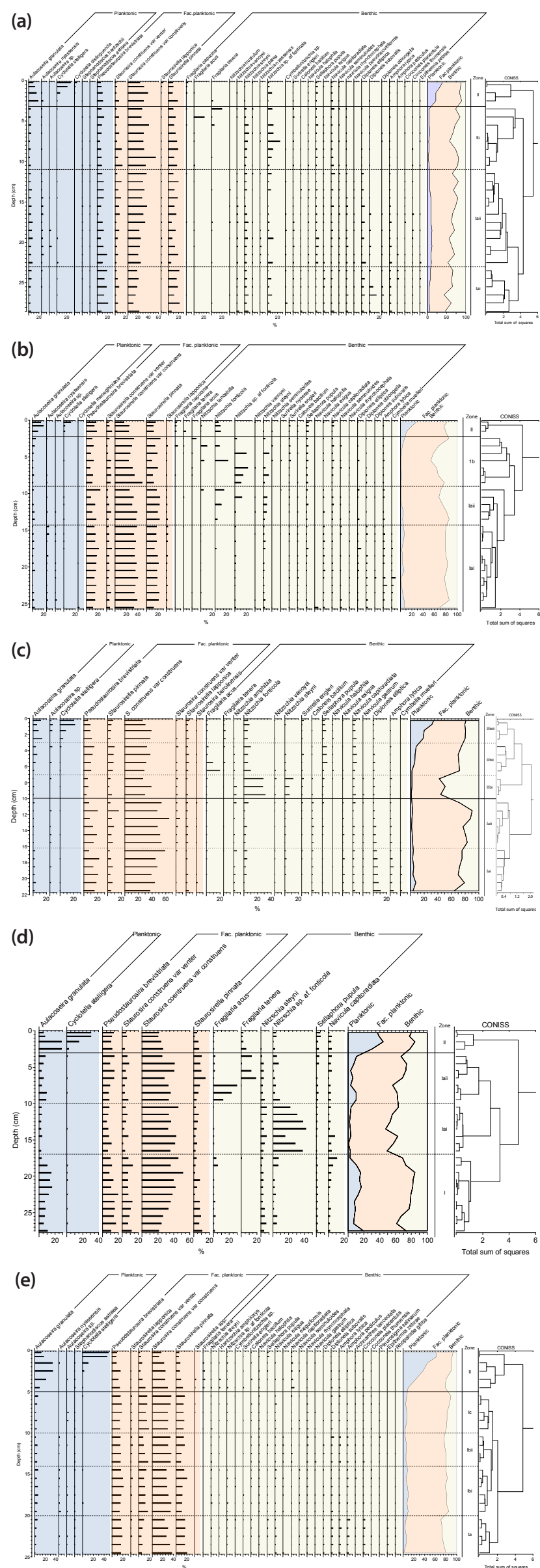

A. nyassensis O. Müller and other unidentified Aulacoseira species, which are probably varieties of A. granulata or A. nyassensis. Other common planktonic species are Cyclotella stelligera, C. distinguenda, an occasional presence of C. meneghiniana, Stephanodiscus astrea, and S. hantzschii.

A general characteristic of all the cores is that the zone with the highest abundance of Nitzschia fonticolas Gasse is superseded by a zone of Fragilaria species. In MAL08E this succession is not well-defined if at all present. Amphora pediculus (Kütz) Grün seems to be restricted only to cores MAL08A and MAL08E, which are near the shore, and a zone dominated by euryhaline diatom species is almost absent in MAL08D.

Two main zones (with four to five main subzones depending on the core) were identified using CONISS. Based on the diatom assemblages in each of the identified subzones, the following generalised stratigraphy was delineated for the cores:

\section{Subzone a}

The main diagnostic species in this zone are Diploneis spp., including D. subovalis Cleve, D. Oblongella Naegelli, D. elliptica, Amphora species, e.g., Amphora lybica Ehr., A. pediculus (Kütz) Grün. (only MAL08E and MAL08A) and an occasional presence of epiphytic diatoms, e.g., Cymbella species and Cocconeis thumensis (epiphytic or epipelic) and epiphytic, freshwater or brackish C. placentula (Patrick and Reimer, 1966; Ryves et al, 2011), depending on site of core. These conditions indicate low water levels with submerged macrophytes.

\section{Subzone b}

This subzone is characterised by a decrease of species in Subzone a and some increase of planktonic species (especially Aulacoseira spp.). This subzone is not well-developed in some cores.

\section{Subzone c}

This zone is characterised by the largest abundance of Nitzschia species, especially Nitzschia fonticola (sensu Gasse, 1986). Other forms include $N$. desertorum, $N$. palea Kütz, N. nyassensis, $N$. frustulum (Kütz) Grün. and N. subrostellata Hust.

\section{Subzoned}

This is a zone characterised by Nitzschia spp. above Subzone c. Nitzschia fonticola are found at the base of this zone and give way to a small subzone characterised by the appearance of Fragilareaceae species. The common species of Fragilaria in this zone are F. acus, F. rumpens and F. tenera at the very top. In cores MAL08B and MAL08E, this zone is not distinctive as it overlaps with the upper Subzone e.

\section{Figure $4 a$ (top left) \\ Diatom stratigraphy for core MALO8A \\ Figure $\mathbf{4} b$ ( $2^{\text {nd }}$ from top left) \\ Diatom stratigraphy for core MALO8B \\ Figure 4c (middle left) \\ Diatom stratigraphy for core MALOBC \\ Figure $4 d$ ( $2^{\text {nd }}$ from bottom left) \\ Diatom stratigraphy for core MALO8D \\ Figure 4 e (bottom top left) \\ Diatom stratigraphy for core MALO8E}



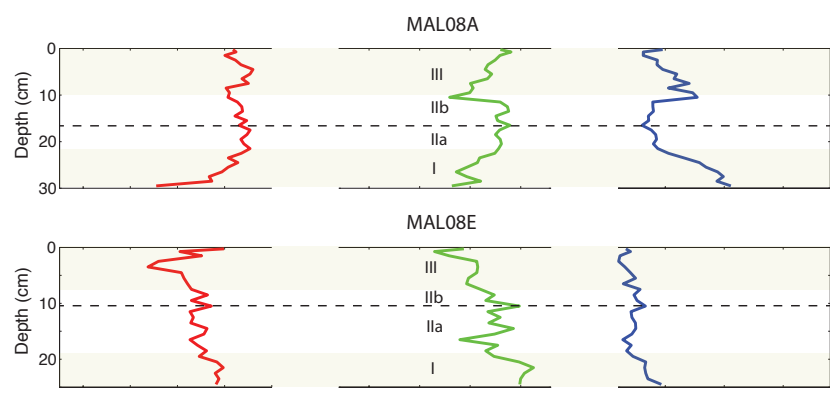

III

$-1$

$$
\text { Ila }
$$

MAL08D

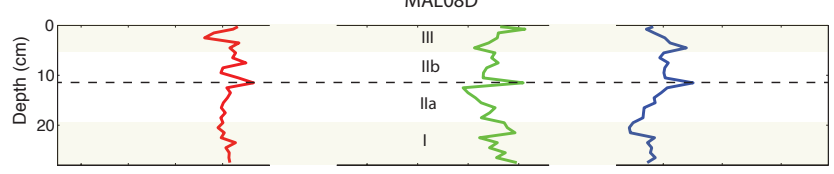

MAL08B
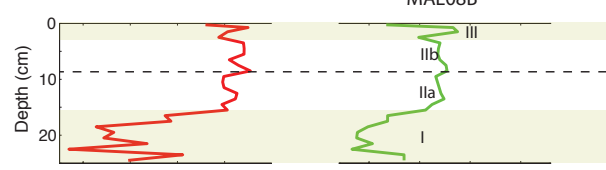

MAL08C
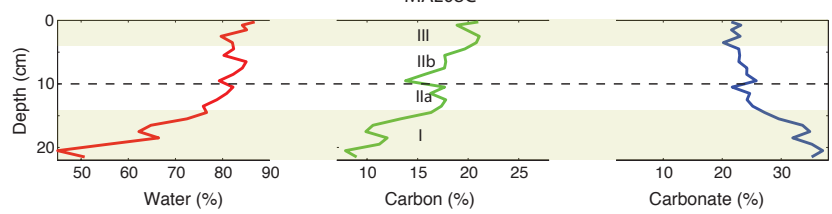

Figure 5

Zoned loss on ignition (LOI) diagrams for Lake Malombe cores. Zone numbers (I, II, III) demarcated by dotted horizontal lines

\section{Subzone e}

Characterised by higher abundance of planktonic taxa compared to the rest of the core. Common planktonic species in this zone include various types of Aulacoseira with A. granulata Ehr being the most dominant. Other forms include A. nyassensis $\mathrm{O}$. Muller and other non-identified Aulacoseira forms designated spp.. Although these species thrive in freshwater lakes, they are tolerant of turbid waters. Other planktonic species include Cyclotella stelligera (Cleve) Grün., Stephanodiscus hantschii Grün. and S. astraea Grün. The zone dominated by Aulacoseira species gives way to a zone dominated by Cyclotella stelligera and $C$. distinguenda (in MAL08A) at the topmost parts of the core.

\section{Loss on ignition}

Moisture, organic carbon and carbonate content are variable between cores (Fig. 5). Three main zones have been defined and are summarised as in Table 3.

\section{TABLE 3}

Summary of main zones demarcated from loss on ignition (LOI) diagrams

\begin{tabular}{|l|c|c|c|c|c|}
\hline \multirow{2}{*}{ ZONE } & \multicolumn{5}{|c|}{ CORE DEPTH INTERVAL (CM) } \\
\cline { 2 - 6 } & MAL08A & MAL08B & MAL08C & MA08D & MA08E \\
\hline I & $21-30$ & $17-25$ & $14-22$ & $20-29$ & $18-25$ \\
\hline II & $10-21$ & $5-17$ & $4-14$ & $5-20$ & $6-18$ \\
\hline III & $0-10$ & $0-5$ & $0-4$ & $0-5$ & $0-6$ \\
\hline
\end{tabular}

\section{Zone I}

All the cores indicate higher carbonate concentration at depth, consistent with the carbonate basal sediments, with maximum values of approx. $20-40 \%$ in MAL08B and MAL08C which are near the centre of the lake compared to $0-10 \%$ for MAL08D and MAL08E from near the littoral zone.

\section{Zone II}

This zone is generally characterised by stable values for all the compounds although some peaks were observed in all the cores but quite pronounced in MAL08A, MAL08D and MAL08E at about 11 and $12 \mathrm{~cm}$, respectively, and could constitute a subzone (demarcated by a dotted line and denoted $\mathrm{a}$ and $\mathrm{b}$ in the diagrams) within this time interval.

\section{Zone III}

This zone occupies the topmost parts of all the cores. The patterns shown are variable from one core to the other.

The zone boundaries demarcated from the LOI curves seem to coincide with the lithostratigraphy of the sediments. The LOI results show that the carbonate content is highest in the two cores that are near the centre of the lake. The high carbonate increase in these cores coincides with a decrease in both water and carbon. MAL08D and MAL08E have the highest carbon content at depth.

\section{DISCUSSION}

The study used transect-sampling multi-proxy techniques to test their potential for environmental reconstruction in a shallow tropical freshwater lake. The reconstructions from Lake Malombe have highlighted various processes and mechanisms responsible for modern environmental conditions, including sediment erosion and deposition processes within the lake basin, climatic hydrological conditions of the lake and water quality. The summary of environmental conditions in the lake based on diatom stratigraphy is presented in Table 4.

\begin{tabular}{|l|l|l|}
\hline \multicolumn{3}{|c|}{$\begin{array}{c}\text { TABLE 4 } \\
\text { Summary of environmental history of Lake Malombe } \\
\text { based on key diatom assemblages }\end{array}$} \\
\hline Zone & Key diatom assemblage & Environmental condition \\
\hline Zone e & Planktonic diatoms & $\begin{array}{l}\text { Higher lake-stand } \\
\text { with polluted waters; } \\
\text { advanced phase of algal } \\
\text { blooms }\end{array}$ \\
\hline Zone d & Fragilaria spp. & $\begin{array}{l}\text { High competition for } \\
\text { silica amongst diatoms } \\
\text { leading to algal blooms }\end{array}$ \\
\hline Zone c & Nitzschia fonticola & $\begin{array}{l}\text { Nitrogen-enrichment } \\
\text { phase with some pres- } \\
\text { ence of blue-green algae }\end{array}$ \\
\hline Zone b & Planktonic diatoms & Fresh lake \\
\hline Zone a & $\begin{array}{l}\text { Euryhaline/ } \\
\text { Polyhypertrophic diatoms }\end{array}$ & Dried-up, polluted lake \\
\hline
\end{tabular}

Results from the bathymetry survey indicate a step which has been attributable to a shallow NS-trending normal fault truncating the western shore of the lake. The core length results further indicate that there is little inter-core variability which 
might imply that there is little sediment disturbance due to turbid flows away from the centre of the lake where the Shire River flows. However, the results obtained from the transect area indicate an inverse relationship in general between the core lengths (amount of sediment accumulation) and lake depth, i.e., less sediment at greater depth. The implication of this relationship is that there might be increased sedimentation along the lake's edges. This is probably a reflection of enhanced siltation processes along the lake margin due to land-use activities, e.g., deforestation and agriculture which are the biggest sources of sediment input into the lake (Rusuwa et al., 2006; Palamuleni et al., 2011). On the other hand, there is a significant sediment loss in the centre of the lake due to the Shire River flowing throughout the lake and hence eroding and removing sediment.

The results from the dating exercise are not reliable to estimate rates of sedimentation for the area. However, sedimentation rates ranging from 1.2 to $1.6 \mathrm{~mm} / \mathrm{a}$ were estimated for Lake Malawi using radiometric techniques (Owen et al., 1990; Branchu et al., 2005). The data from depth sounding from the bathymetry section indicate that the lake is flat-bottomed and, because of this, Lake Malombe may not be functioning as a 'normal' lake with sediment focused towards a deeper central zone, because of the Shire River that passes through the central part of the lake. Apart from temporal changes observed by the top-bottom shifts in fossil assemblages, changes associated with lateral shifts in space are evident. In particular, there are differences between the fossil assemblages and LOI results between cores nearer the centre of the lake and cores from near the shore. These differences imply different habitats, probably related to hydrological, morphometrical and ultimately environmental conditions along the transect area. Water and carbon variability in the cores could be influenced by other factors such as porosity, macrophyte growth in shallow environments and basin characteristics in general. These effects may mask the environmental signal of the lake and need to be considered while choosing and interpreting the proxies.

The sediment stratigraphy has indicated a change from carbonate- to clastic-dominated (fine sand, silt and mud) sediments from the bottom to the top and from nearshore to offshore, indicating a decrease in salinity in the area. This is based on both LOI and diatom (e.g. Amphora species) results. The lack of distinctive sedimentary layering of the carbonates is interpreted as evidence that they were probably formed from dissolved carbon dioxide from an anaerobic environment during the period of lake recession in the 1920s (Nyasaland Protectorate, 1926). The sharp contact between the carbonate clays and the overlying clay unit probably indicates a stratigraphic gap reflecting delayed deposition or sediment erosion in the basin when the lake began to refill. The dominance of fine clastics above the clay carbonate is related to an increase in siltation due to deforestation and agriculture within the catchment basin (Palamuleni, 2011). Above the carbonate clays, fine clastics dominate. These fine clastic sediments indicate a lake level rise after the 1920s major recession. The transition from lime-dominated to clastic-dominated sediments is an indication of lake transgression (Khin and Myitta 1999).

The Secchi measurements obtained in this study are in marked contrast to Secchi disk values of $2.4 \mathrm{~m}$ obtained by GOM/FAO/UNDP (1993) at 4-m depth compared to 0.9, 1.2 and $1.3 \mathrm{~m}$ at depths of $3.6,4.6$ and $4.2 / 4.8 \mathrm{~m}$, respectively. The discrepancy in these measurements could be attributed to a variety of factors, such as the sites where measurements were taken, seasonality, increasing turbidity and measurement errors. However, the differences between the two studies are almost twice as much within a gap of almost 20 years. The errors associated with seasonality are considered minimal considering the dry season when the samples were collected. The consistency between the cores and large discrepancy between the 1993 and the 2008 results cannot be ascribed to measurement errors but could rather indicate an increase in turbidity of the lake; thus decreased water quality of the lake seems to be the most likely explanation. Although the results from the measurements in this study are inconclusive if used on their own, they have been interpreted together with other observations (e.g. rapid increase of the planktonic species at the top parts of the cores) from other proxies, thereby strengthening the validity of the interpretations. The results from this study indicated a Secchi depth range of $0.9-1.3 \mathrm{~m}$ for the lake. Accordingly, the lake may be classified as mesotrophiceutrophic based on the classification of Dobson and Frid (2009).

Despite the uncertainties in the dates obtained and some missing diatom zones in other cores, the diatom responses exhibit a consistent pattern from one core to the other. This consistency implies that these responses could be useful to unravel the environmental history of the lake. In general, the planktonic taxa present, e.g., Aulacoseira granulata, Navicula capitoradiata, are alkaliphilous, indicative of oligosaline or freshwater environment. However, the absence of some of these zones e.g. Fragilaria zone in MAL08B and Nitzschia zone in MAL08E, highlights the danger of drawing conclusions of an ox-bow lake environment based on a single core. In this case, the transect approach may be highly recommended. Furthermore, diatoms have proved to be very sensitive to the various environmental changes that have taken place in the lake and thus are reliable tools for environmental reconstructions even in unstable hydrological environments such as these.

The top-bottom shifts in diatom species composition observed in the cores are attributable to a number of environmental factors. The largest percentage of the cosmopolitan species is contributed by Fragilaria spp. Apart from their endemicity to the eastern Africa region, Fragilarians have also been described as indicators of unstable environments due to their broad ecological tolerance ranges (Reed, 1996). Pseudostaurosira brevistriata (conductivity optimum $=2.76$, $\mathrm{pH}$ optimum $=7.82$ ), Staurosira construens var. construens (conductivity optimum $=2.71, \mathrm{pH}$ optimum of 8.39 ), Staurosira construens var. venter (conductivity optimum $=2.71$ and $\mathrm{pH}$ optimum $=8.39$ ) and Staurosirella lapponica (conductivity optimum $=2.86, \mathrm{pH}$ optimum $=8.58)($ Gasse et al., 1995). These species are opportunistic, thriving in the epipelic littoral environments with favourable light conditions (Bennion et al, 2001). Thus the dominance of these cosmopolitan diatom species throughout the cores suggests that this lake is an unstable environment probably attributable to fluvio-laccustrine behaviour of the lake and high silt loads. Despite the difficulties in interpreting environmental conditions associated with these diatoms, the presence of deformed forms of $S$. construens could imply some level of contamination (Falasco et al., 2009). This observation is also supported by the presence of eutrophication-tolerant species such as Gomphonema parvulum, Cyclotella meneghiniana and Achnanthes spp. near the littoral zone. The large presence of benthic species in the cores is generally indicative of a generally shallow and clear-water lake that existed after the 1920 desiccation event. However, based on their assemblages a number of environmental conditions can be inferred.

The increased carbonate at depth indicates the 1920s desiccation event and is a useful stratigraphic marker. This period 
is dominated by aerophilous, epipelic and epiphytic species, some euryhaline and polyhypertrophic diatom species in Zone a and some littoral species, e.g., Cymbella spp., Diploneis spp., Hantzschia amphioxys, Amphora spp. and Pleurosigma salinarum. These diatoms reflect a macrophyte-dominated shallow, muddy lake with increased salinity. The occasional presence of Cyclotella meneghiniana, which is pollution-tolerant and indicative of permanent to semi-permanent waters, may imply some increased levels of eutrophication that existed in some of the shallow water pools.

A brief but stable lake period followed after the 1920s desiccation event up to the 1950s. An expanding population of Mangochi Township and an increase in water usage led to the increase in nitrogen, possibly from sewer systems and agricultural activities. This period is denoted by a rapid increase in Nitzschia fonticola. The ecology of Nitzschia fonticola is not well defined, partly as a result of difficulties in identification of this species. Gasse (1986) describes this group as occurring in diverse habitats ranging from hot springs to plankton of freshwater bodies. Cholnoky (1968) considers Nitzschia fonticola to be a nitrogen heterotrophy, often thriving in colonies of cyanobacteria in stable thermally-stratified lakes and with wide tolerance ranges (Kilham et al., 1986; Marks and Power, 2001). Cyanobacteria have a high growth requirement for phosphates (Kilham et al., 1984). The abundance of these Nitzschia species in Zone c (probably between 1950 and 1975) is interpreted in this work as an indication of the beginning of a phosphate-enrichment phase in the lake, considering that cyanobacteria thrive in areas where phosphorus is in abundant supply (Kilham et al., 1986). This phase is probably related to expanding agricultural fertiliser usage (e.g., tobacco farming) and detergent usage from the nearby Mangochi Township.

Zone d (probably the post-1975 to early 1990s period) is indicated by an abundance of Fragilaria species (F. acus with conductivity optimum of $2.21, \mathrm{pH}$ optimum 8.08 , and S. rumpens with a conductivity optimum $2.34, \mathrm{pH}$ optimum 7.8; Gasse et al., 1995). These species are known as best competitors for phosphorus and growing best where silica is not limited (Tilman, 1981; Kilham, 1984). This period reflects an increase in biogenic silica resulting from nutrient enrichment in Zone $\mathbf{b}$ and higher competition for phosphates amongst the diatom species. In addition, the Fragilaria species tend to shift towards more planktonic than benthic species. For example, the observed shift in composition from F. rumpens to F. tenera (Gasse, 1986, Krammer and Lange-Bertalot, 1991a) is probably an indication of competition for light amongst these species as the water clarity is reduced.

As siltation and nutrient enrichment increased in the lake, water clarity reduced, and, with a combined nutrient input from other activities, the planktonic species (mostly Aulacoseira spp.) seem to have taken over dominance from the benthic species in modern times (Zone d). Dominance of Aulacoseira granulata (conductivity optimum 2.56, $\mathrm{pH}$ optimum 7.66) and presence of Stephanodiscuss hantzschii (conductivity optimum 2.80, pH optimum 8.90) may indicate a temporary high stand but also increased levels of phosphate enrichment (Reed et al., 2001). Combined with observed differences in Secchi disk measurements between the early 1990s and 2008, the diatom response data provide further evidence of reduced water clarity in the lake.

In summary, the environmental history of the lake is clearly shown, from Secchi disk measurements, LOI and diatom diagrams, as being classified into two main periods from the 1920s. The earliest period has a clear climate signal and the second period is dominated by an anthropogenic signal. The increased calcium content of sediments and a zone having only shallow-water benthic and littoral diatoms are evidence for increased aridity (evaporation), or reduced rainfall, suggesting a climate-related phase at the base of the Lake Malombe cores. This period was followed by a relatively stable and clean lake phase before the modern and polluted phase.

\section{ACKNOWLEDGEMENTS}

The study was supported by a Commonwealth split-site PhD scholarship award (Hull, UK) to Zuze Dulanya by the Graduate School of the University of Potsdam (Germany). We also would like to extend our gratitude to Mark Anderson from the University of Hull for laboratory technical support. Mr OK Mhone, formerly of the Fisheries Department in Monkey Bay, provided invaluable assistance in the field work.

\section{REFERENCES}

ABRAM NJ, GAGAN MK, HANTORO WS, MCCULLOCH MT, CHAPPELL J and SUWARGADI BW (2007) Seasonal characteristics of the Indian Ocean Dipole during the Holocene epoch. Nature 445 299-302. DOI:10.1038/nature05477.

ANNADOTTER H, CRONBERG G, AAGREN R, LUNDSTEDT B, NILSSON P and STRÖBECK S (1999) Multiple techniques for lake restoration. Hydrobiologia 395/396 77-85.

BARBOUR MT, SWIETLIK WF, JACKSON SK, COURTEMANCH DL, DAVIES SP and YODER CO (2000) Measuring attainment of biological integrity in the USA: a critical element of ecological integrity. Hydrobiologia 422/423 453-464.

BATTARBEE RW (1986) Diatom analysis. In: Handbook of Palaeoecology and Palaeohydrology. John Wiley and Sons, Chichester.

BATTARBEE RW (1999) The importance of palaeolimnology to lake restoration. Hydrobiologia 395/396 149-159.

BATTARBEE RW (2000) Palaeolimnological approaches to climate change, with special regard to the biological record. Quaternary Sci. Rev. 19 107-124.

BATTARBEE RW, JUGGINS S, GASSE F, ANDERSON NJ, BENNION H, CAMERON NG, RYVES DB, PAILLES C, CHALIE $F$ and TELFORD R (2001) European Diatom Database (EDDI). An information system for palaeo-environmental reconstruction. ECRC Research Report No. 81. Environmental Change Research Centre, University College London, London. 94 pp.

BATTARBEE RW, ANDERSON NJ, JEPPENSEN E and LEAVITT PR (2005) Combining palaeolimnological and limnological approaches in assessing lake ecosystem response to nutrient reduction. Freshwater Biol. 50 (1) 1772-1780.

BELLINGER BJ, COCQUYT C and O’REILLY CM (2006) Benthic diatoms as indicators of eutrophication in tropical streams. Hydrobiologia 573 75-87.

BENNION H, WUNSAM S and SCHMIDT R (2001) Reconstructing nutrient histories in the Norfolk Broads, UK: Implications for the role of diatom-total transfer functions in shallow lake management. J. Palaeolimnol. 26 181-204.

BOOTSMA H and JORGENSEN SE (2005) Lake Malawi/Nyasa: Experience and lessons learned. Brief in companion CD-ROM for ILEC. Managing Lakes and their Basins for Sustainable Use: A Report for Lake Basin Managers and Stakeholders. International Lake Environment Committee Foundation, Kutsatsu, Japan.

BRANCHU P, BERGONZINI L, DELVAUX D, DE BATIST M, GOLUBEV V, BENEDETTI M and KLERKX J (2005) Tectonic, climatic and hydrothermal control on sedimentation and water chemistry of northern Lake Malawi (Nyasa), Tanzania. J. Afr. Earth Sci. 43 433-446.

CARTER GS and BENNET JD (1973) The geology and mineral resources of Malawi. Bull. Geol. Surv. Malawi 6.

CASTAÑEDA IS, WERNE JP and JOHNSON TC (2007) Wet and 
arid phases in the southeast African tropics since the Last Glacial Maximum. Geology 35 (9) 823. DOI:10.1130/G23916A.1.

CHOLNOKY BJ (1968) Die Okologie der Diatomeen in Binnengewasser. J Cramer,

Lehre.

CURRIE LA (1968) Limits of qualitative detection and quantitative determination. Anal. Chem. 40 (3) 586-593.

DEAN WE (1974) Determination of carbonate and organic matter in calcareous sediments and sedimentary rocks by loss on ignition: comparison with other methods. J. Sedim. Petrol. $44242-248$.

DIGERFELDT G (1986) Studies on past lake-level fluctuations. In: Berglund BE (ed.) Handbook of Holocene Palaeoecology and Palaeohydrology. John Wiley, Chichester.

DIXEY F (1932) The Portland Cement Clays of Lake Malombe. Bull. Geol. Surv. Malawi 4.

DOBSON M and FRID C (2009) Ecology of Aquatic Ecosystems. Oxford, London.

EDDI (EUROPEAN DIATOM DATABASE) (2012) European Diatom Database. URL: http://craticula.ncl.ac.uk/Eddi/isp/ (Accessed 15 April 2012).

FALASCO E, BONA F, GINEPRO M, HLÚBIKOVÁ D, HOFFMANN L and ECTOR L (2009) Morphological abnormalities of diatom silica walls in relation to heavy metal contamination and artificial growth conditions. Water SA 35 (5) 595-606.

GASSE F (1986) East African diatoms: Taxonomy, ecological distribution. Bibliotheca Diatomologica, Band 11. ISBN: 978-3-443-57003-3.

GASSE F, JUGGINS S and BEN KHELIFA L (1995) Diatom-based transfer functions for inferring past hydrochemical characteristics of African Lakes. Palaeogeogr. Palaeoclimatol. Palaeoecol. 117 31-54.

GENNER MJ, MICHEL E, ERPENBECK E, DE VOOGD N, WITTE F and POINTIER J (2004) Camouflaged invasion of Lake Malawi by an Oriental gastropod. Mol. Ecol. 13 2135-2141.

GILMORE G and HEMINGWAY J (2000) Practical Gamma-Ray Spectrometry. John Wiley, Chichester.

GOM/FAO/UNDP (1993) Fisheries management in south-east Lake Malawi, the Upper Shire River and Lake Malombe. CIFA Technical Paper 21. FAO, Rome.

GRIMM EC (1987) CONISS: A Fortran 77 program for stratigraphically constrained cluster analysis by the method of incremental sum of squares. Comput. Geosci. 13 (1) 13-35.

GRIMM EC (1991) TILIA and TILIA GRAPH. Illinois State Museum, Springfield, IL.

HECKY RE (1993) The eutrophication of Lake Victoria. Verh. Int. Ver. Theor. Angew. Limnol. 25 39-48.

HECKY RE, BOOTSMA HA and KINGDON MJ (2003) Impact of land use on sediment and nutrient yields to Lake Malawi/Nyasa (Africa). J. Great Lakes Res. 29 (Suppl. 2) 139-158.

HEIRI O, ANDRE FL and LEMCKE G (1999) Loss on ignition as a method for estimating organic and carbonate content in sediments: reproducibility and comparability of results. J. Paleolimnol. 25 $101-110$.

KALK M, MCLACHLAN AJ and HOWARD-WILLIAMS C (1979) Lake Chilwa. Studies of Change in a Tropical Ecosystem. Dr W Junk, The Hague.

KANTHACK FE (1941) The fluctuations of Lake Malawi [Nyasa]. Geogr. J. $120-23$.

KELLER AA and CAVALLARO L (2008) Assessing the US Clean Water Act 303(d) listing process for determining impairment of a waterbody. J. Environ. Manag. 86 699-711.

KELLY M, BENNETT C, COSTE M, DELGADO C, DELMAS F, DENYS L, ECTOR L, FAUVILLE C, FERREOL M, GOLUB M, JARLMAN A, KAHLERT M, LUCEY J, NI CHATHAIN B, PARDO I, PFISTER P, PICINSKA-FALTYNOWICZ J, ROSEBERRY J, SCHRANZ C, SCHAUMBURG J, VAN DAM H and VILBASTE S (2008) A comparison of national approaches to setting ecological boundaries in phytobenthos assessment for the European Water Framework Directive: results of an intercalibration exercise. Hydrobiologia. DOI: 10.1007/s10750-008-9641-4.

KHIN K and MYITTA K (1999) Marine transgression and regression in Miocene sequences of northern Pegu (Bago) Yoma, Central Myanmar. J. Southeast Asian Earth Sci. 17(3) 369-393.
KILHAM SS (1984) Silicon and phosphorus growth kinetics and competitive interactions between Stephanodiscus minutus and Synedra spp. Int. Ver. Theor. Angew.Limnol.Verh. 22 435-439.

KILHAM P, KILHAM SS and HECKY RE (1986) Hypothesized resource relationships among African planktonic diatoms. Limnol. Oceanogr. 31 1169-1181.

KITNER M and POULICKOVA A (2003) Littoral diatoms as indicators for the eutrophication of shallow lakes. Hydrobiologia 506-509 519-524.

KLING HJ, MUGIDDE RM and HECKY RE (2001) Recent change in the phytoplankton community of Lake Victoria in response to eutrophication. In: Munawar M and Hecky RE (eds) The Great Lakes of the World (GLOW): Food-Web, Health and Integrity. Backhuys Publishers, Leiden.

KOLDING J, VAN ZWIETEN P, MKUMBO O, SILSBE G and HECKY RE (2008) Are the Lake Victoria fisheries threatened by exploitation or eutrophication? Towards an ecosystem-based approach to management. In: Bianchi G and Skjodal HR (eds) The Ecosystem Approach to Fisheries. CAB International, Wallingford.

KRAMMER K and LANGE-BERTALOT H (1986) Bacillariophyceae. 1 Teil: Naviculaceae. In: Ettl H, Gerloff J, Heynig H and Mollenhauer D (eds) Susswasserflora von Mitteleuropa. Gustav Fischer Verlag, Stuttgart. $886 \mathrm{pp}$.

KRAMMER K and LANGE-BERTALOT H (1988) Bacillariophyceae. 2 Teil: Bacillariaceae, Epithermiaceae, Surirellaceae. In: Ettl H, Gerloff J, Heynig H and Mollenhauer D (eds) Susswasserflora von Mitteleuropa. Gustav Fischer Verlag, Stuttgart. 596 pp.

KRAMMER K and LANGE-BERTALOT H (1991a) Bacillariophyceae. 3 Teil: Centrales, Fragilariaceae, Eunotiaceae. In: Ettl H, Gerloff J, Heynig $\mathrm{H}$ and Mollenhauer D (eds) Susswasserflora von Mitteleuropa. Gustav Fischer Verlag, Stuttgart. 576 pp.

KRAMMER K and LANGE-BERTALOT H (1991b) Bacillariophyceae. 4 Teil: Achnanthaceae Kritische Erganzungenzu Navicula (Lineolatae) und Gomphonema. In: Ettl H, Gerloff J, Heynig H and Mollenhauer D (eds) Susswasserflora von Mitteleuropa. Gustav Fischer Verlag, Stuttgart. 437 pp.

LANCASTER N (1981) Formation of the Holocene Lake Chilwa sandbar - Southern Malawi. Catena 8 (3/4) 369-382.

MANYOZO DM, M'NDALA AT and PHIRI FR (1984) The geology of Lake Malombe Area. Bull. Geol. Surv. Malawi 33.

MARKS JC and POWER ME (2001) Nutrient-induced changes in the species composition of epiphytes on Cladophoraglomerata Kütz. (Chlorophyta). Hydrobiologia 450 187-196.

MOSS B and MOSS V (1969) Aspects of the Limnology of an Endorheic African Lake (L. Chilwa, Malawi). Ecology 50 (1) 109-118.

MPAWENAYO B and MATHOOKO JM (2005) The structure of diatom assemblages associated with cladophora and sediments in a highland stream in Kenya. Hydrobiologia 544 55-67.

MSISKA OV and LWANDA AG (2008) Trophic fluctuations in Lakes Malawi and Malombe. In: Proceedings of the 2008 Annual Research Conference. National Research Council of Malawi. Lilongwe, Malawi.

NICHOLSON S (1998) Fluctuations of rift lakes Malawi and Chilwa during historical times: a synthesis of geological, archaeological and historical information. In: Lehman JT (ed.) Environmental Change and Response in East Africa. Kluwer Academic Publishers, Dordrecht.

NICHOLSON SE and YIN X (2001) Rainfall conditions in equatorial East Africa during the nineteenth century as inferred from the record of Lake Victoria. Clim. Change 48 387-398.

NYASALAND PROTECTORATE (1926) Annual Report of the Geological Survey of the 1926. Bull. Geol. Surv. 4.

OTU MK, RAMLAL P, WILKINSON P, HALL RI and HECKY RE (2011) Paleolimnological evidence of the effects of recent cultural eutrophication during the last 200 years in Lake Malawi, East Africa. J. Great Lakes Res. 37 61-74.

OWEN RB, CROSSLEY R, JOHNSON TC, TWEDDLE D, KORNFIELD I, DAVIDSON S, ECCLES DH and ENGSTROM DE (1990) Major low levels of Lake Malawi and their implications for speciation rates in cichlid fishes. Proc. R. Soc. London 240 519-553.

PALAMULENI LG, NDOMBA PM and ANNEGARN HJ (2011) 
Evaluating land cover change and its impact on hydrological regime in Upper Shire river catchment, Malawi. Reg. Environ. Change. DOI: 10.1007/s10113-011-0220-2.

PATRICK R and REIMER CW (1966) The diatoms of the United States, exclusive of Alaska and Hawaii, Volume I - Fragilariaceae, Eunotiaceae, Naviculaceae. Acad. Nat.Sci. Phila. Monogr. 13.

PLATER AJ, HORTON BP, HAWORTH EY, APPLEBY PG, ZONG Y, WRIGHT MR and RUTHERFORD MM (2008) Holocene tidal levels and sedimentation rates using a diatom-based palaeo-environmental reconstruction: the Tees estuary, northeastern England. The Holocene 10 (4) 441-452.

REED JM (1996) The potential of diatoms, ostracods and other indicators for Holocene palaeoclimate research in southern Spanish salt lakes. Limnetica 12 25-39.

REED JM, STEVENSON AC and JUGGINS S (2001) A multi-proxy record of Holocene climatic change in southwestern Spain: the Laguna de Medina, Cadiz. The Holocene 11 (6) 707-719.

RUSUWA B, MARUYAMA A and YUMA M (2006) Deterioration of cichlid habitat by increased sedimentation in the rocky littoral zone of Lake Malawi. Ichthyol. Res. 53 431-434.

RYVES DB, MILLS K, BENNIKE O, BRODERSEN KP, LAMB AL, LENG MJ, RUSSELL JM and SSEMMANDA I (2011) Environmental change over the last millennium recorded in two contrasting crater lakes in western Uganda, eastern Africa (Lakes Kasenda and Wandakara). Quaternary Sci. Rev. 30 (5-6) 555-569.

SAJI NH, GOSWAMI BN, VINAYACHANDRAN PN and YAMAGATA T (1999) A dipole mode in the tropical Indian Ocean. Nature 401 360-363.

SAYER CD and ROBERTS N (2001) Establishing realistic restoration targets for nutrient-enriched shallow lakes: linking diatom ecology and palaeoecology at the Attenborough Ponds, UK. Hydrobiologia 448 117-142.

SAYER CD, ROBERTS N, SADLER J, DAVID C and WADE PM (1999) Biodiversity changes in a shallow lake ecosystem: a multi-proxy palaeolimnological analysis. J. Biogeogr. 26 97-114.

SCHOLZ CA, JOHNSON TC, COHEN AS, KING JW, PECK JA, OVERPECK JT, TALBOT MR, BROWN ET, KALINDEKAFE L, AMOAKO PYO, LYONS RP, SHANAHAN TM, CASTAÑEDA
IS, HEIL CW, FORMAN SL, MCHARGUE LR, BEUNING KR, GOMEZ J and PIERSON J (2007) East African megadroughts between 135 and 75 thousand years ago and bearing on earlymodern human origins. URL: www.pnas.org/cgi/content/ full/0703874104/DC1 (Accessed 16 February 2010).

SCHULTHEISS R, VAN BOCXLAER B, WILKE T and ALBRECHT C (2009) Old fossils - young species: evolutionary history of an endemic gastropod assemblage in Lake Malawi. Proc. R. Soc. London Series B, Biol. Sci. 276 2837-2846.

SHELA O (2000) Naturalisation of Lake Malawi levels and Shire River flows: Challenges of water resources research and sustainable utilisation of the Lake Malawi-Shire River System. 1st WARFSA/ WaterNet Symposium: Sustainable Use of Water Resources, 1-2 November 2000, Maputo. URL: http://www.bscw.ihe.nl/pub/bscw. cgi (Accessed 15 April 2012).

SNOEKS J (1998) Taxonomy and ichthyodiversity research on the African Great Lakes: a comparison. In: Coetzee L, Gon J and Kulongowski C (eds) International Conference for the Paradi Association and the Fisheries Society of Africa. FISA/PARADI, Grahamstown, South Africa.

STAGER JC, WESTWOOD J, GRZESIK D and CUMMING BF (2005) A 5500-year environmental history of Lake Nabugabo, Uganda. Palaeogeogr. Palaeoclimatol. Palaeoecol. 218 347-354.

STOERMER EF and SMOL JP (ed.) (1999) The Diatoms: Applications for the Environmental and Earth Sciences. Cambridge University Press, Cambridge.

THOMAS DSG, BAILEY R, SHAW PA, DURCAN JA and SINGARAYER JS (2009) Late Quaternary highstands at Lake Chilwa, Malawi: Frequency, timing and possible forcing mechanisms in the last $44 \mathrm{ka}$. Quaternary Sci. Rev. 28 526-539.

TILMAN D (1981) Tests of resource competition theory using four species of Lake Michigan algae. Ecology 62 802-815.

VESKI S, HEINSALU A, KLASSEN V, KRIISKA A, LOUGAS L, POSKA A and SALUAAR U (2005) Early Holocene coastal settlements and palaeo-environment on the shore of the Baltic Sea at Parnu, southwestern Estonia. Quaternary Int. 130 75-85.

WILLIAMS DM and ROUND FE (1987) Revision of the genus Fragilaria. Diatom Res. 2 267-288. 
http://dx.doi.org/10.4314/wsa.v40i4.17 Available on website http://www.wrc.org.za

ISSN 0378-4738 (Print) = Water SA Vol. 40 No. 4 October 2014 ISSN 1816-7950 (On-line) = Water SA Vol. 40 No. 4 October 2014 